\title{
VERSITA
}
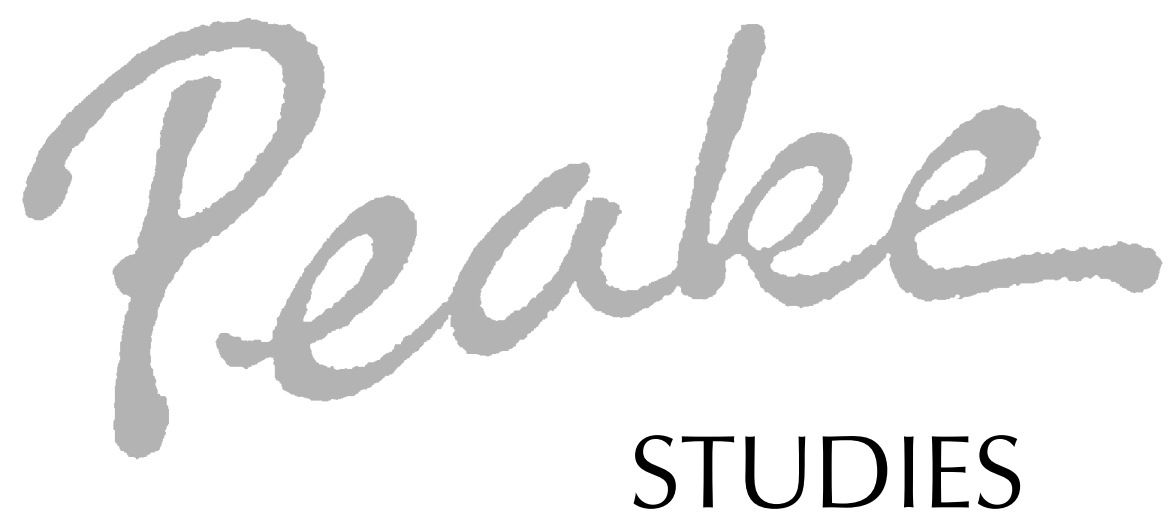

Vol. 13 , no 2

April 2013

Unless otherwise indicated, the contents of Peake STUDIES are (C) G Peter Winnington 2013.

Acknowledgement is made to the Mervyn Peake Estate for permission to reproduce Mervyn Peake's words and images. Unless otherwise indicated the previously unpublished works by Mervyn Peake in this issue are (C) the Mervyn Peake Estate 20I3.

Edited and published by G Peter Winnington, 2 ch du Collège, I 453 Mauborget, Switzerland.

Tel. +4I 244362232 E-mail peakestudies@gmail.com Home page http://peakestudies.com 


\section{The Things They Say}

Another lightly edited trawl of the web, in chronological order

New Build's Al Doyle interviewed by CLASH (9 March 2012)

At the moment I often think about scenes and characters from Gormenghast by Mervyn Peake, which for some inexplicable reason I've neglected to read until very recently. Exquisite, unbelievably finely observed descriptions, huge and terrifyingly real characters - and a massively surprising and thematically disconnected third part to the trilogy, after a completely engrossing first two parts. In case you hadn't guessed, I loved it. Unique in literature as far as I know - it has more than a splash of Dickens, and some debts to the gothic novels, I guess, but it inhabits its own world and needs no company. It is complete. http://www.clashmusic.com/feature/their-library-new-build

\section{Identity Crisis}

From a review of Boy in Darkness and other stories by Anastasia Klimchynskaya (who 'just doesn't get along with Peake') posted on 23 March 20I 2: 'Peake's collection of tales seems to be having a sort of internal identity crisis, oscillating desperately between simplicity and attempted complexity.'

http://blogcritics.org/books/article/book-review-boy-in-darkness-and/

From 'Titus in the Land of Nightmares' by Alastair Savage posted on I3 May $20{ }_{2} 2$

Peake belongs to no world but his own. His work is utterly different to what has gone before and what will come after. He has no contemporaries, no rivals and no followers. His work, like the vast edifice of Gormenghast Castle, occupies its own space in our world and yet out of it, known and yet forgotten. 
As modern people, we are surrounded by stories. We have access to more drama through television alone than Peake's contemporaries had in their entire lifetimes. This means that we have developed a silent storyline in our heads.... There are rules to narrative structure, and we know and expect the author to follow them.

Peake breaks all the rules, and rejects that well-trodden path. This makes his work tremendously exciting. As readers we have no idea where he is taking us. Just look at the deaths that characters suffer in the course of the Gormenghast novels: they are drowned, stabbed, starved, poisoned, struck by lightning, burnt to death, and in one particularly alarming incident, eaten by owls.

There is always something different, something surprising around the next corner. Peake bewilders us, and rejects the infantilized world of story-telling. As any parent knows, children love predictability. They will often ask to hear the same story read to them time and time again. There is a security that comes in knowing what will come next. There is no such security in the world of Gormenghast.

Especially not in the traumatic shadow land of Titus Alone, the third book in the series.... Imagine for a moment that Peake gave up writing after completing Gormenghast, the second book of the series. Many years later, a publisher decides that it is worth continuing his story, and commissions a well-known (if poorly compensated) writer to bash out a third title. If there is one hypothesis that we can make in this situation, it is that our new writer will not write anything like Titus Alone. In fact, were a putative new author to submit the manuscript of Titus Alone, there's a very good chance that the editorial team would reject it on sight. With its sudden appearance of helicopters and cars, its swearing and its references to bodily functions, its vague setting and dreamlike intentions, Titus Alone feels like another book entirely, something quite different to its illustrious predecessors.

Titus Alone reveals something vital about Mervyn Peake, as both author and artist. He was on a different journey to that which anyone else could have imagined. This is why Peake will never go out of fashion, and will keep getting new readers. Although many people will be appalled by the Goya-esque darkness, torture and misery of 
Titus Alone, there is no doubt that it is a work of genius, with its own unique texture and tone. Titus Alone is not like anything else on earth. It is not even Titus Groan meets Gormenghast. As with all Peake's work, I'm enormously surprised that it was ever published at all. Surely, a large part of that success lies in his wonderful prose style: his descriptions of herons in chapter I 2 of Gormenghast might well be the most beautiful thing I have read all year.

http://alastairsavage.wordpress.com/2012/05/13/titus-in-the-land-ofnightmares/

From the blog of fantasy writer Ash Silverlock

posted on 30 September 2012

Titus Groan and the world of Gormenghast is a creation of unbridled fantasy unlike any other. Peake writes convincingly, using words in unusual ways, making them work harder, making them sidle into unfamiliar situations; much as the reader is presented with an unfamiliar and daunting world of shadows and misery in Gormenghast. Yet although the picture painted is a dark one, it is not without its beauty. Peake's brilliance is in his creativity even when it seems to serve little purpose. There are many descriptions of small facets of Gormenghast which bear no relation to any other, save that they build up the reader's picture of its world.

http://silverlock.wordpress.com/2012/09/30/titus-groan-by-mervyn-peake

From 'Umbrageous Legacy: Mervyn Peake's Portrait Gallery'
$\begin{aligned} & \text { by Sofia Samatar } \\ & \text { posted on } 9 \text { October } 20 \text { I } 2\end{aligned}$

Philip Best, who served with him during Peake's war years, remembers how, wherever and whenever possible, 'Gunner Peake' would take out his stub of pencil and draw, 'in complete happiness and wrapped within himself,' and with 'tremendous purpose and concentration.'

'That,' Best adds, 'was Peake's discipline' (Winnington, p.I33). But the image of Peake here suggests a person in the grip of something altogether more spontaneous and satisfying than discipline. 
The combination of purpose, concentration and 'complete happiness' fits both art and play. The page is a little world, an enclosure to be filled by the artist's design; imaginatively, the artist enters this space, so that to an outside observer he appears 'wrapped within himself.' Without trivializing the artist's work in any way, I want to suggest that the enclosed space of the work of art shares an affinity with the pirate ship, which is bound upon adventures but is also a little world, of which the pirate captain is the absolute ruler. 'Her name was the Black Tiger,' Peake writes of the ship in his picture book, 'and Captain Slaughterboard ruled her - every inch!' This type of enclosure differs from the Gothic type, which is imposed from the outside. This enclosure is built, and claimed, from within a larger structure, as a child's pirate vessel is constructed of living-room chairs. The dangers and mishaps of adventure fiction are pleasurable in part because of the enclosures created in opposition to them: the cave, the campsite, the boat.

Here, then, is a way of reading enclosure and compression in Peake's fiction: as a form of play. The joy of the game glimmers in Titus's marbles: 'Oh, beautiful marbles! Oh, blood-alleys! Oh, clouded ones, aswim in blood and milk! Oh, crystal worlds, that make the pockets jangle - that make the pockets heavy!' (p.400). These pocket worlds inspire more than a passing delight: Fuchsia Groan's love for her private universe, her attic, 'equals in its power the love of man for woman and reaches inwards as deeply' (p.58). The child's love for the secret enclosure is the love of all human beings for 'the world of their centre where their lives burn genuinely and with a free flame.' It is the diver's love of the sea, the farmer's love of the earth, and also 'the love of the painter standing alone and staring, staring at the great coloured surface he is making' (p.59).

A different way of reading enclosure; and also, perhaps, a different way of reading excess. For all their preoccupation with compression, the Gormenghast novels are sprawling, unwieldy things, with an organic feel, like shrubs allowed to grow wild. This is the complement to scribbling small: doodling out of proportion. Again, I don't wish to trivialize Peake's work by the comparison. Doodling, a form of play using pencil and paper, is also a type of improvization, of 
experimentation, yielding unexpected and sometimes striking results. The impulse toward embellishment, toward drawing outside the lines, gives the Gormenghast novels their fascinating bulges and extra appendages, such as the stream-of-consciousness monologues of the chapter 'The Reveries' in Titus Groan, or the elaborate preparations for Irma Prunesquallor's party in Gormenghast. Doodling, less controlled than drawing, allows for humor and transgression. Far from being too adult for the eyes of 'sensitive children,' the 'horrific' portraits of Captain Slaughterboard, bristling with the energy and wickedness of doodles, may be too childish for sensitive adults.

The child's secret world, where joyous grotesquerie proliferates, is for Peake the center of life. To betray it is a crime. This is what gives his story 'Same Time, Same Place' its atmosphere of loss. On the surface, 'Same Time, Same Place' is the story of a youth who escapes a ghastly bride; underneath, it concerns a child's loss of his secret world. Though the narrator is nearly twenty-three years old, his childish character is obvious from the first sentence: 'That night I hated Father' (p.I3I). It is equally clear that he is right to hate the 'dark, smug mortality' of his parents' home (p.I32) and escape to Piccadilly Circus. He goes there in search of adventure, which he imagines taking place in a private enclosure: 'How wonderful it would have been to have known of some apartment, dimly lighted; of a door that opened to the secret knock' (p.I33). His dream comes true, not in a dim apartment, but in a crowded restaurant, where he meets and falls in love with a majestic lady. The enclosure appears later, as the window that frames the narrator's view of the office where he is to meet and marry his love. Within that frame, the hand of a diabolical doodler has been at work: the horrified husband-tobe sees a bearded lady, a man with 'the longest neck on earth,' a tattooed man, a man with a cloven hoof in place of one of his hands, and lastly his diminutive bride, who resembles 'a mechanical doll' (p.I39).

These grotesques are portrayed as absolutely malignant. Yet the young man's return to his parents' dull home reads as tragic. Terror shares space with romance (same time, same place); in fleeing the apparently horrible, the young man has closed the door on his pri- 
vate world, and betrayed both his bride and himself. 'Since then I have never left the house,' he declares (p.I43): an image of a perverted enclosure, where the child-narrator will always belong entirely to his parents, and where transgression and art are impossible. $\mathrm{Mr}$ Slaughterboard, an early iteration of the Captain, loathes the thought of such cowardice: 'If I ever disobey the artist within me, may my eyeballs turn to blood, and my tongue become a fungus' (p.69).

The work of Mervyn Peake was made possible by his absolute fidelity to the closed space of art, a fidelity so difficult to sustain that we see it only rarely, and which will always result in works that are sui generis. His oeuvre is a legacy both umbrageous and quicksilverbright, full of glowering portraits that always retain a hint of the absurd, and lugubrious halls in which a child has fashioned a hideyhole and is enjoying a feast of seed cake and dandelion wine. Although the exquisitely vile Steerpike steals most of the scenes in Gormenghast, it is after all Titus Groan who is the hero: Titus with his pocket full of crystal worlds, whose true home is not Gormenghast Castle but a castle in the air. For first and ever foremost he is child.

\section{Sources}

Mervyn Peake, The Gormenghast Trilogy. Overlook Press, I988.

-_- Peake's Progress. Penguin Books, I98 I.

-_- Boy in Darkness and Other Stories. Peter Owen, 2007.

G. Peter Winnington, Vast Alchemies: The Life and Work of Mervyn Peake. Peter Owen, 2000.

http://weirdfictionreview.com/2012/10/weirdfictionreview-coms-101weird-writers-12-mervyn-peake/

From the blog of Aaron Jansen, 'a 21-year-old college graduate from Minnesota, USA' posted on 20 November 2012 Gormenghast feels real, more so than any fictional place I've encountered in literature. The people who live there seem like real people; the things that happen there happen slowly, over swaths of time, as 
in real life; the structure of the castle begins to take on weight, solidity, tactility...

But not just real - more than real, hyper-real, real in a way that can only exist in art. Allow me to briefly digress: I am not a terribly observant person, on the whole, and I tend to go about my daily existence blind to the wealth of detail that surrounds me. I have occasional moments of transcendent noticing - of being suddenly and vividly aware, of having my senses opened up - but so much I tune out, so much fades into a background murmur. The Gormenghast books, in their greatest moments, provide a dizzying density of sensory information, a concentration of reality that seems to transcend the real thing - because no one, in real life, could possibly notice so much. Peake's marvelous knack for noticing has taught me a great deal as a writer: he has taught me to always keep my eyes peeled, and that believable fictional worlds are made up, not of elaborate invented mythologies, but of these little bits and pieces of the world we inhabit, distilled, distorted, and rearranged.

That hyper-real quality extends beyond Peake's physical descriptions of the castle; the series is absolutely suffused with it. In the world that Peake creates everything approaches the real, but is finally too much, too vivid, although it's only once you've left the books and fallen back to earth that you realize how everything in that other world was a little askew. While you read, the plot seems to proceed at a pace resembling that of real life, but then you return to the real world, where years do not pass in pages. The characters, likewise, seem absolutely real as you read: they are perfect products of their environment; they fit Gormenghast like a glove. But then you leave Gormenghast, and you realize that they, too, were grotesques, too wholly themselves to be real people.

The second book is an organic expansion of the first; the atmosphere is seamlessly sustained as new characters are introduced, new avenues of the castle explored. Gormenghast follows Titus over the course of ten years, from seven to seventeen, and as he becomes a more prominent member of the cast the book quite naturally evolves into a coming-of-age story. Peake's treatment of this theme is totally consistent with his style: Titus's experiences are taken seriously, 
given real emotional weight, and are specific enough to be those of a real adolescent - but Peake lends them an unreal clarity and intensity. The mystery of Peake's writing is how through this dreamlike exaggeration, rather than in spite of it, he manages to arrive at the universal. Take the passage in which Titus, frustrated with the senseless code of ritual to which he is bound, runs away from home and loses his way in the surrounding forest; he stumbles upon an otherworldly golden glade, glimpses a feral child who haunts the woods, and falls desperately in love with her. She is totally separate from the world of the castle and totally mysterious to him; the very idea of her is enchanting. Why should this first love - no doubt unlike any experienced in the real world - seem such a perfect representation of all first loves? Peake writes like he is digging to China: he scratches away so ferociously, so obsessively, at a specific feeling, image, or sensation that, before you know it, he has tunneled all the way through the specific and popped out at the universal end of the spectrum.

There are so many things that Mervyn Peake does well.... Let us also note that the Gormenghast books are often really funny. Peake is seemingly incapable of writing a boring line of dialogue, and much of the banter between characters is hilarious. He can also - notwithstanding silly complaints (by tasteless philistines) that the books are plotless - write an absolutely harrowing action scene: Steerpike's increasingly ruthless murders are as suspenseful as anything I've read. The Gormenghast books are rich. They explore just about the full possibilities of fiction.....

Titus Alone is not, unfortunately, a third masterpiece - but, you know what, it feels petty to pick apart a book written as its author was in the throes of a debilitating degenerative disease. Rather than approach this book as the definitive ending to a series - because it wasn't even intended to be in the first place - think of this third installment as a generous gift, a bonus supplement, a kind of happy miracle. Its existence, especially in this current state of faithfulness to Mervyn Peake's vision, is an unlikely blessing.

The Gormenghast series feels much more believable to me than most fantasy because the books build a world from the ground up, 
beginning with a foundation of concrete imagery. They contain no magic and no elves, but are nonetheless some of the most purely fantastic books I have ever read in their evocation of another world, a world which seems, at times, to supersede our own in splendor. As a writer I find Mervyn Peake's unique fantasy vision inspiring - one gets the sense that he wrote what he wanted to write, period, and that's what fantasy should be, right? As a reader I appreciate that the books engage on so many different levels; most books are box lunches, but each of these is a banquet. Once you've read Gormenghast, you may find that other books seem a little flat, a tad lifeless, not quite complete.

http://poorlytitled.wordpress.com/2012/11/20/book-review-thegormenghast-series/

Seen something in the press or on the web? Read a good book that mentions Peake? Remember to pass on the news and your views to the Editor for inclusion here! 